\title{
City as a Personality: New Concept of Creative City
}

\author{
Matej Jaššo ${ }^{1}$, Zuzana Ladzianska ${ }^{2}$ \\ \{matej.jasso@stuba.sk ${ }^{1}$, zuzana.ladzianska@stuba.sk $\left.{ }^{2}\right\}$
}

Slovak University of Technology in Bratislava, SPECTRA Centre of Excellence, Vazovova 5, 81243 Bratislava, Slovakia ${ }^{1}$, Slovak University of Technology in Bratislava, SPECTRA Centre of Excellence, Vazovova 5, 81243 Bratislava, Slovakia ${ }^{2}$

\begin{abstract}
New role of the European cities within the processes of cooperation and competition highlighted their need for unique, highly profiled and strategically managed identity. Need for unique, original and plausible profile of each city, aspiring to be successful in the process of regional competition has been confirmed to be utterly urgent. Creativity is one of the most fundamental preconditions of success in this competition and is substantial also in the process of fostering the place attachment, sense of belonging and togetherness of the inhabitants and in many other fields. Recently, creative city goes far beyond pure technological innovations and is more concerned with the management of the self-image of the city. Struggling for competitive advantage of the particular city is based on the strategic and creative managerial approach toward city personality - unique set of characteristics and traits specific for particular city. The article refers on the concept of City as a Personality, covering the results of perception of various elements of city identity: values, face, social climate, key traits and characteristics etc. Fundamental preconditions for efficiency of such concept are introduced and discussed.
\end{abstract}

Keywords: city identity, city as a personality, creative city, values, creativity

\section{Introduction}

Cities are becoming one of the most complex artificial systems worldwide. Every city possesses unique identity based on the highly profiled urbanity and its multifaceted elements and projections. Post-modern urbanity might be understood as the unique quality of urban spaces forwarded by cities to their citizens in terms of communication and sociability [1]. Urban spaces have been actively co-created by users and are representing the ontological processes of mankind [2]. The sense of urban space is never terminal and is continuously changing, thus urban and metropolitan milieu is an example of ultimate complexity on territorial level. This milieu displays manifold hierarchical and horizontal structures and dimensions and is dealing with plethora of contraversions and conflicts. Urban environment is yielding many positive (urban imagery, fun, celebration...) and negative (urban anxiety, urban panic, alienation...) connotations. Urban imagery is always fragmented, reterritorialized, heterogonous, diasporic, or even split apart. An important tool to creative interpretation and "reading" the urban environment is urban semiotics, studying the social meaning of spatial forms and settings. Urban semiotics involves the exploration of physical objects and their 
endowed meanings as mediated through a universe of signs and the symbols they evoke and convey [3]. In urban semiotics the city is seen as "the text based on the grammar of spatial patterns and structures generating meaning" [4]. Creativity in many semiotic forms is an essential part of any city development.

\section{Creative Cities}

Creativity might be defined as unique ability of human personality to find new and non/traditional approaches to known problems, topics, solutions. According to Gardner [5] creative person "regularly solves problems, fashions products, or defines new questions in a domain in a way that is initially considered novel but that ultimately comes to be accepted in a particular cultural setting". Creative thinking is not mere individual process but rather a social phenomenon based on the interactions of various actors and intersection of various social contexts [6]. Sawyer [7] states, that "creativity isn't just a property of individuals, it is also a property of social groups". City as a social macro system is one of the most fruitful social structures in terms of creativity.

Large and robust debate on the topic of creative cities is lasting more than 20 years (see e.g. [8], [9], [10]). It is obvious, that cities are more than pure settlement structures or accumulation of labour and capital - they are unique social organisms, patterns of manifold human interactions and therefore creating historically and geographically specific forms of creativity (more in [6]). Various collective decision-making and behavioural patterns are enhancing creativity as one of the most essential characteristics of successful, smart and sustainable city. Cities need creativity to be places with unique existential values, to be successful in recent competition of European cities and regions, to survive processes of transition etc. Past troubles have been solved by decomposition of the problem situation and by the physical intervention. Today we know, that "more sustainable environments will not be created if we only look at the environmental dimension; we also have to address how people mix and connect, their motivations and whether they take responsibility and "own" where they live and change their lifestyles appropriately." [9]. Although the creativity in the relation to the urban environment is the heritage of modernity, the old normative rational concepts of planning often failed to introduce creative solutions. Organised modernity was celebrating everything new, unknown, different from the traditional, but the result was often a setback, a disappointment, a disillusion. Today we need rather divergent than convergent creativity, "we need the creativity of being able to synthesize, to connect, to gauge impacts across different spheres of life, to see holistically, to understand how material changes affect our perceptions, to grasp the subtle ecologies of our systems of life and how to make them sustainable. We need skills of the broker." [9]. Participative and collaborative planning approaches redefined also the role of creativity in planning and city development: broadening the scope of the planning actors and stakeholders increased also the creative input and learnt the cities to better adopt to the rapidly changing external environment and fostered new dynamics in the process of city development.

We are witnessing the process of redefinition of what does it mean creative city. City is being approached as a learning system, a living organism able to adapt, handle and overcome the new problems and challenges utilising its own unique endogenous potential. Cities are 
becoming carriers of values and behavioural patterns, which are fostering the sense of identification by their citizens, visitors or other actors. It is obvious that increased importance of the ethic criteria of the communication process in the city management is outgoing from the previous statements. Only if the system is intelligent and smart enough, the consequences from previous behaviour can be taken into account and thus the system itself is able to correct, modify and evaluate its inner potential. The behavioural autonomy, high ethical standards and strongly profiled identity are inseparable parts of these systems. The maintenance and development of these fields is a basic supposition for the development of own unique and memorable identity. Since 2009 crisis we have been witnessing the gradual changes in value profile of the society. The values like innovativeness, sustainability, creativity, quality and user friendliness have continuously won the priority. In opposite, the linear technological development (represented mainly by car use boom) or massive building development processes have a little bit faded away. Concept of smart city, reflecting this value shift and searching for optimal ways of satisfaction of social, economic and ecological needs and demands could be named for all. Smart and intelligent solutions are extraordinary important just in urban environment (not only because of high share of urbanisation, but also because of extraordinary dynamic and thus high conflict occurrence of the processes externalised in urban environment), and cannot be reduced to pure technological innovations. Ability to learn and forget, ability to interpret chaos and ability to work in virtual networks and environments are prime examples of the new skills which should be added to smart/creative city profile. Recently we have recorded also the value split and polarisation tendencies in the entire society. It is impossible to meet the differentiating needs of the target auditorium in by obsolete, inefficient and more or less normative ways. Creativity is a fundamental precondition of innovation efficiency, and there is always some "optimal threshold of resistance" (Melucci, in [9]) when implementing innovative solutions in creative milieu.

\section{City as a Personality}

Plethora of analogies between the city and any other systems has appeared in recent years. Scholars have approached city as a company, living organism, computer model and so on. Concept of City as a Personality is based upon the analogy between human individual and the city. Human personality - as well as the personality of any other entity (company or city) is the foundation of identity: it differentiates an individual from a multitude of others in an absolutely accurate and explicit way [11, 12]. Every personality is unique sample and combination of various characteristics, traits or personal qualities. Even such rationalistic and functionalism theoretician as Otto Wagner [13] wrote on "mimics and physiognomy" of the face of the city. Although personality is a psychological construction - as a concept of identity, differing the individual from the others, it might find valuable utilisation in the context of the city identity. Richard Powell [14] in his highly influential novel The Philadelphian states:"Of the major cities of the United States, only nine have distinct and individual personalities. These are New York, Chicago, Philadelphia, Boston, Los Angeles, San Francisco, New Orleans, Charleston, and Savannah. ...In order to stimulate writers, the personality of a city or town need not be lovable. I hope I am not revealing anything top secret when I say that, too many outsiders, Philadelphia and Boston have highly irritating personalities. To many outsiders, these two cities are rather like a pair of sheltered maiden ladies who have become crotchety and eccentric but who happen to be awfully well-heeled.". 
If the city has highly profiled personality, it is easier to identify with such role model: citizens, residents, visitors, investors or member of any other relevant subgroup are more prone to identify with the subject which is legible, coherent and communicative. Place attachment of people is based upon the spontaneous mechanisms (memory, sense of togetherness and pride) but might be actively fostered and supported by the official communication of the city. Construct "City as a Personality" might be a helpful tool in this field.

\section{Element of the City Personality}

Fundamental dimension of any personality are values. In metaphorical way values deliminate the whole ideology, attitudes, approaches and cognitive styles of the personality. Various cities have their typical values (conservative, liberal, environmental) which are materialised in many forms and ways. We might analyse typical underlying values of given city, their historical and cultural origin and sources, current manifestation, stability in time and space, internal consistence and acceptance from the target groups. Interpretation of these values is also constantly changing (certain place or architectural form might be interpreted differently in various historic eras) and the context (political, social, spatial, cultural, semiotic) plays an essential role.

Another important part of the city personality is its face and visual appearance. We can analyse the irreplaceable visual attributes of the city (landmarks, symbols, and signs), physiognomy and mimics of the city, its compatibility with declared values, emotions arisen by the "face" of the city. The visual language might be coherent or fragmented/split apart and specific facial expressions might play essential role in the visual language of the city. With certain degree of metaphorical and imaginative thinking we can analyse whether the facial expression of the city is in concordance with identity and values or whether there are signs of urban dissimulation, affectation, hypocrisy or any other psychological mechanism. Visual language of the city might be universal or specific and its general legibility might be highly context driven or culture free. Main part of the face of the city is often the city centre - as an obvious urban focal point is usually a result of long-term cultural and historical development, as well as socio-economic process. The city centre retains its visual stability (mainly meaning stability) and is in the most cases the central topic of the emotional added value of the city, concentration of its identity.

Language of the city is another part of its personality. We might concentrate both on architectural language and its syntax as well as the verbal language of the city. Various architectural grammar and syntax, language dualities observed within the city (vernacular vs. political language, metropolitan vs. provincial/rural language), specific "newspeak" of the city, and carriers of the language trends are further fields for survey and research.

Indisputable part of city personality is its temper, emotions, spirit and social climate. We might investigate which reactions are typical: is the city rather phlegmatic, sangvinic, melancholic, or choleric? Reactions of the city are very often related to the reactions of city representatives. They are represented by their actions/non-actions, communication with the public, openness toward incoming guests, as well as preparedness for new investments. Many cities are struggling with specific urban anxiety and traumas, recent wounds, injuries, and 
scars. They can be represented by abandoned sites, neglected areas, former industrial sites, empty plots in urbanised structure; all of them located in diverse places around the city. Similar to human personality; city has also battle with expressions of neuroticism, affects, social pathologies or posttraumatic stress reaction.In Central-East Europe we can relate mainly to the transition period after the political change at the end of the 1980's when countries and their cities were looking for new path of existence and new communication approaches[15].

We may analyse the body ("gestalt") of the city and its physical integrity as well as the boundaries. Spirit of certain places is highly indicative for emotions of the personality of the city, often the whole atmosphere is changing within time cycles (summer-winter, night-day, morning-evening). For the personality of the city it is important to be prepared and reflect the atmosphere changes in the physical structure of the city (lightning, temporary ice-skating rings or swimming pools, mobile architecture, etc.). Prevailing social climate might be coherent, friendly, hostile, split apart, indifferent, smooth, open-minded, snobbish, eerie, ambiguous, collaborative, endangering, positive, supportive, envy, etc. which is visible and readable differently in each part of the city. In the past years the phenomenon of gentrification of city centres has been intensively discussed and has a substantial influence on the overall social climate [16].

Every city is becoming typical through its abilities, skills, characteristics and traits. Many concepts of SMART city or creative city are based on the set of unique abilities of the city to manage its spatial, economic, social and cultural life. Cognitive style of the city, its ability to learn new skills and to "read" the context is often main competitive advantage of the city not only in international competition, but moreover in the process of fostering the place attachment and quality of life of its own citizens. SMART city is more than a city whose traffic models are directed by computers, or where citizens and visitors can communicate and share the information via free $\mathrm{Wi}-\mathrm{Fi}$ spots connected to electronic devices docking stations, it is highly sensitive entity able to learn from the past.

\section{How to Develop City Personality as a Part of Creative City Strategy?}

From the beginning of the millennium we have been witnessing the boom of the projects, promoted through the title of the SMART/creative city. We were dismayed by the width of the range of the projects, tasks and methods which can be found under the label of SMART/creative city. All the factors and criteria enabling easy classification of the mentioned projects and proceedings could not be delimited till now. As time goes by, it seems indicative that the SMART/creative city concept goes beyond the pure technological innovations and must sensitively utilise long array of subtle and soft factors.

The following criteria could be considered as the general and most relevant:.

- Long term duration and conceptual nature of any creative city concept.

- Integrative and interdisciplinary approach to problem substance elaboration.

- Participation of all stakeholders on the vision and creation of the personality of the given city.

- Close connection of the planning to the implementation. 
- Local needs and potentials have to be taken into consideration.

- Consensus and coordination of the activities.

- Flexible organisation structure and decision making mechanisms.

- Long term partnership between the public and private field.

- More attention dedicated to the soft tools and imaginative way of thinking instead of pure "technocratic" approaches.

The most decisive factor is close connection to target auditorium, mainly toward the citizens. The basic supposition of the efficiency regarding all the measures within the creation of the city as a personality is trustworthiness. One of the most important characteristics of successful work in the field of creating a city as a distinguished personality is work effort precisely aimed to the selected target groups (enterprise bodies, citizen's initiatives, gastronomy, tourism). It is necessary to distinguish the view from the external (investors, tourists, and media) and internal audience (citizens, local entrepreneurs, youngsters). The goals leading to satisfaction of the needs of both groups may not be in contradiction. That is the reason, why the detailed and deep analysis of the city personality as well as the analysis of the needs and expectations of the various target groups should be in the spotlight. The attention of the various creative city initiatives is often aimed on fields like retail, gastronomy, tourism, sport and leisure time activities, housing, traffic, work places etc. One of the basic conditions to be able to assure efficiency of the processes running under the title of the creating city as a personality is the mutual information exchange and willingness to communicate among the participants of the process. This is necessary to be taken into account if the coordination of the realised measures and maximisation of positive effect has to be guaranteed.

\section{Conclusion}

City as a personality is an integrated concept, providing theoretic and methodological framework for the problem solutions on the community level. It is necessary to be aware of the fact, that creating city a personality is not a substitution for the local authorities' policy, but it can be an effective strategic and tactical tool helping to externalise and implement the goals of the local authority policy.

\section{Acknowledgments}

This contribution is the result of the project implementation: SPECTRA+ No. 26240120002 "Centre of Excellence for the Development of Settlement Infrastructure of Knowledge Economy" supported by the Research \& Development Operational Programme funded by the ERDF. 


\section{References}

[1] CASTEllo, L. (2007) Metaurban Tourist Places and City Development. In Holcim Forum for Sustainable Construction; Urban Trans Formation (Shanghai, 18.-21.4 2007).

[2] LEFEBVRE, H. (1991) The Production of Space. (Oxford: Blackwell Publishing).

[3] KEKKER, S. (1988) Review on Gottdiener, M., Lagopoulos, A.: The City and the Sign: An Introduction to Urban Semiotics. Contemporary Sociology, Vol. 17 (No. 3 - May): 346-348.

[4] JACHNA, T. (2004) Cyburban Semiotics. (First published at COSIGN, 14-16th September 2004) (Croatia: University of Split).

[5] GARDNER, H. (1993) Creating Minds: An Anatomy of Creativity Seen through the Lives of Freud, Einstein, Picasso, Stravinsky, Eliot, Graham, and Ghandi. (New York).

[6] De HAAN, R.L. (2009): Teaching Creativity and Inventive Solving in Science. CBE Life SciEduc, Vol. 8 (No. 3 - fall): 172-181.

[7] SAWYER, K. (2006) Explaining Creativity: The Science of Human Innovation, (Oxford University Press).

[8] FLORIDA, R. (2002) The Flight for the Creative Class. (New York: Harper Collins Books).

[9] LANDRY, Ch. and BIANCHINI, F. (1995) The Creative City. (London: Demos Publishing).

[10] SCOTT, A.J. (2006) Creative Cities: Conceptual Issues and Policy Questions. Journal of Urban Affairs, Vol.28 (Nr.1): 1-17.

[11] JAŠŠO, M. and KUBO, L. (2015) Urbánna sémiotika. (Bratislava: Spectra - ROAD).

[12] JAŠŠO, M.: Miasto jako osobowosc. Autoportret Journal. Kwartalnik Malopolskieho Instytutu Kultury. Vol. 36 (No. 1): 88-93.

[13] HALÍK, P., KRATOCHVÍL, P., and NOVÝ, O. (1996) Architektura a město. (Praha: Academia).

[14] POWELL, R. (2007) Preface to the 50th Anniversary Edition of The Philadelphian: The Personality of Philadelphia. (Plexus Publishing).

[15] THORNS, D. C. (2002) The Transformation of Cities. (New York: Palgrave MacMillan).

[16] LEES, L., SLATER, T. and WYLY E. (2008) Gentrification. (New York/London: Routledge/Taylor \& Francis Group). 